\title{
EVALUASI PAKAN SUPLEMEN MINYAK IKAN LEMURU DAN HIDROLISAT DARAH TERPROTEKSI BERDASARKAN KECERNAAN BAHAN KERING DAN KECERNAAN BAHAN ORGANIK DI DALAM RUMEN DAN PASCA RUMEN
}

\author{
A. Pramono ${ }^{1}$, Kustono ${ }^{2}$, D. T. Widayati ${ }^{2}$, P. P. Putro ${ }^{3}$ dan H. Hartadi ${ }^{2}$ \\ ${ }^{1)}$ Program Studi Peternakan, Fakultas Pertanian, Universitas Sebelas Maret, Surakarta \\ ${ }^{2)}$ Fakultas Peternakan, Universitas Gadjah Mada, Yogyakarta \\ ${ }^{3)}$ Fakultas Kedokteran Hewan, Universitas Gadjah Mada, Yogyakarta \\ Email: ahmad.pram@staff.uns.ac.id
}

\begin{abstract}
ABSTRAK
Peningkatan asupan energi pada ternak ruminansia dapat dilakukan dengan meningkatkan energi pakan menggunakan lemak (minyak). Asupan protein dapat ditingkatkan dengan pemberian protein terproteksi yang dapat lolos degradasi oleh mikrobia rumen. Tujuan dari penelitian ini adalah untuk mengevaluasi kemampuan pakan suplemen terproteksi berbahan baku minyak ikan lemuru sebagai sumber energi dan hidrolisat darah sebagai sumber protein untuk digunakan sebagai pakan suplemen ternak ruminansia berdasarkan kecernaan bahan kering $(\mathrm{KcBK})$, dan kecernaan bahan organik $(\mathrm{KcBO})$ secara in vitro di dalam rumen dan pasca rumen. Proteksi minyak ikan lemuru dan hidrolisat darah dilakukan dengan metode penyabunan dan mikroenkapsulasi. Penelitian ini menggunakan rancangan acak lengkap pola searah dengan 3 perlakuan (pakan suplemen, bungkil kedelai dan rumput pangola), masing-masing perlakuan diulang sebanyak 5 kali. Data yang diperoleh diolah dengan analisis variansi. Hasil penelitian tahap satu di dalam rumen menunjukkan bahwa pakan suplemen terproteksi memiliki KcBK 24,46\% dan KcBO 57,17\%, bungkil kedelai memiliki KcBK 75,20\% dan KcBO: 75,66\%, rumput pangola memiliki KcBK 50,81\% dan KcBO 59,21\%. Kecernaan tahap dua (pasca rumen) pakan suplemen memiliki KcBK 69,04\% dan KcBO 66,7172,76\%, bungkil kedelai memiliki KcBK 90,38\% dan KcBO 88,23\%, dan rumput pangola memiliki KcBK 63,24\% dan KcBO 59,21\%. Hasil penelitian disimpulkan bahwa pakan suplemen paling tahan dari degradasi mikrobia di dalam rumen dibandingkan dengan perlakuan yang lain dan sabun kalsium dapat terdegradasi dan tercerna di dalam abomasum sampai dengan usus halus.
\end{abstract}

Kata kunci: Pakan suplemen terproteksi, In vitro, KcBK, dan KcBO

\section{Evaluation of Sardine Fish Oil and Hydrolyzate Blood Protected as a Feed Suplement Based on Dry Matter Digestibility, Organic Matter Digestibility in the Rumen and Post Rumen}

\begin{abstract}
Increased of ruminants energy intake can be conducted by increasing the energy density of feed by using fat (oil). Protein intake can be enhanced by increasing of protected protein that escapes degradation by rumen microbes. The Aim of this research was to evaluate protected of feed supplement based on dry matter digestibility $(K c B K)$, organic matter digestibility $(K c B O)$ in vitro in the rumen and post-rumen. Protected feed supplement was produced from sardine fish oil and hydrolyzed blood, throught two protection methodes. It was saponification and microencapsulation. This research uses a completely randomized design with 3 treatments (feed supplements protected, soybean meal and pangola grass), which each treatment was repeated 5 times. The results in the first
\end{abstract}


step (rumen) of the protected feed supplement showed that has dry matter digestibility $24.46 \%$ and organic matter digestibility 57.17\%, soybean meal has dry matter digestibility $75.20 \%$ and organic matter digestibility $75.66 \%$, and pangola grass has dry matter digestibility 50,81\% and organic matter digestibility 59.21\%. In the second step (post rumen) the digestibility of protected feed supplement has dry matter digestibility $69.04 \%$ and organic matter digestibility $66.7172 .76 \%$, soybean meal has dry matter digestibility $90.38 \%$ and organic matter digestibility $88.23 \%$, and the grass pangola have KcBK $63.24 \%$ and $K c B O 59.21 \%$. The results could be concluded that in the rumen protected feed supplementation is the most microbial degradation resistant compared the other and it can be degraded and digested in the abomasum to the small intestine.

Keywords : Protected feed supplements, In vitro, dry matter digestibily, organic matter digestibility

\section{PENDAHULUAN}

Energi dan protein merupakan nutrien utama yang dibutuhkan untuk sintesis hormon, pertumbuhan dan perbaikan jaringan, sintesis susu dan fungsi fisiologis lainnya guna memenuhi kebutuhan hidup pokok, pertumbuhan, produksi susu dan reproduksi ternak (Pramono et al., 2014). Peningkatan asupan energi pada ternak ruminansia dapat dilakukan dengan meningkatkan energi pakan menggunakan lemak (minyak), sedangkan asupan protein dapat ditingkatkan dengan pemberian protein terproteksi yang dapat lolos degradasi oleh mikrobia rumen (Pramono et al., 2013).

Kendala utama pemberian lemak pada ruminansia karena lemak mudah mencair pada kondisi suhu rumen, sehingga dapat menghambat proses fermentasi bahan pakan dan aktivitas mikrobia dalam rumen. Salah satu sumber energi potensial, banyak tersedia, dan harganya murah adalah minyak ikan lemuru. Minyak ikan lemuru mengandung asam lemak tak jenuh tinggi. Suplementasi asam lemak tidak jenuh terbukti dapat meningkatkan efisiensi energi melalui peningkatan densitas energi dan menopang peningkatan efisiensi sintesis protein jaringan melalui peningkatan aliran nitrogen $(\mathrm{N})$ non amonia ke duodenum (Johnson et al., 2002). Kendala yang ditemukan apabila minyak ikan lemuru diberikan secara langsung dalam pakan adalah (1) adanya proses hidrogenasi dalam rumen yang mengubah lemak tak jenuh menjadi jenuh, dan (2) pemberian minyak dapat mengganggu aktivitas mikrobia selulitik, sehingga menurunkan laju fermentasi dalam rumen (Pramono et al., 2014).

Bungkil kedelai merupakan produk sampingan dari ekstraksi minyak dari kedelai utuh (Agus, 2012). Bungkil kedelai memiliki kelebihan yaitu kandungan protein yang cukup tinggi, nilai kecernaannya tinggi, baunya sedap, dan dapat meningkatkan palatabilitas ransum (Kamal, 1998). Namun pemberian bungkil kedelai tanpa proteksi pada sapi perah kecernaannya sangat tinggi dalam rumen sehingga protein tersebut akan dimanfaatkan oleh mikrobia rumen menjadi protein mikrobia.

Perlakuan proteksi dibutuhkan untuk memperoleh manfaat yang nyata dari adanya suplementasi sumber energi dan atau protein dalam pakan.Pada suplementasi asam lemak tidak jenuh proteksi diperlukan untuk menghindarkan asam lemak tidak jenuh dari biohidrogenasi ikatan ganda oleh mikrobia rumen (Ashes et al., 1995). Proteksi juga berguna untuk mengeliminasi dampak negatif suplementasi asam lemak tidak jenuh pada aras tinggi, berupa penurunan degradabilitas serat (Aharoniet al., 2004). Penelitian ini bertujuan untuk mengevaluasi kemampuan proteksi minyak ikan lemurusebagai sumber energi dan hidrolisat darah sebagai sumber protein untuk digunakan sebagai pakan suplemen ternak ruminansia berdasarkan kecernaan bahan kering (KcBK), dan kecernaan bahan organik $(\mathrm{KcBO})$ secara in vitro di dalam rumen dan pasca rumen. 


\section{MATERI DAN METODE}

Penelitian ini dilakukan di kandang percobaan Bagian Nutrisi dan Makanan Ternak, Laboratorium Ilmu Makanan Ternak, Laboratorium Teknologi Makanan Ternak Fakultas Peternakan Universitas Gadjah Mada.

\section{Materi Penelitian}

Ternak yang digunakan pada penelitian ini adalah sapi Peranakan Ongole (PO) betina berfistula rumen sebanyak 2 ekor berumur sekitar tigatahun, dengan berat badan $290 \mathrm{~kg}$ dan $320 \mathrm{~kg}$. Bahan yang digunakan adalah minyak ikan lemuru dan darah sapi segar yang diambil dari rumah pemotongan hewan (RPH) Kecamatan Umbulharjo, Kotamadya Yogyakarta, Propinsi Daerah Istimewa Yogyakarta yang kemudian dihidrolisis dengan $\mathrm{NaOH}$ sehingga menjadi hidrolisat darah sebagai bahan baku pembuatan pakan suplemen. Pembuatan pakan suplemen sabun kalsium menggunakan metode penyabunan dan mikroenkapsulasi.

Bahan-bahan untuk analisis kecernaan in vitro seperti: gas $\mathrm{CO} 2$, cairan rumen, larutan McDougall (saliva buatan) termasuk larutan $\mathrm{CaCl}_{2} \quad 4 \%$ yang ditambahkan menjelang digunakan, $\mathrm{HCl}$ 20\%, dan pepsin 5\%. Peralatan yang digunakan adalah adalah timbangan analitik merk Sartorius dengan kapasitas $150 \mathrm{~g}$, kain kasa, tabung reaksi $50 \mathrm{ml}$, karet penyumbat, waterbath, dispensette, jirigen, crucible, thermos, glasswool, gelas ukur2000 ml, kompor listrik, pipet $5 \mathrm{ml}$, dan ballpump.

\section{Metode Penelitian}

Dua ekor Sapi PO yang digunakan pada penelitian ini, ditimbang terlebih dahulu untuk mengetahui berat badannya sehingga dapat ditentukan kebutuhan pakannya. Kebutuhan bahan kering sapi per ekor menggunakan rumus kebutuhan bahan kering 3\% dari berat badan. Imbangan pakan hijauan: konsentrat adalah $70: 30$. Ransum yang digunakan mengandung protein kasar $12 \%$ dan total digestable nutrients $60 \%$. Bahan pakan yang digunakan untuk menyusun konsentrat terdiri atas konsentrat jadi nutrivit, bran pollard, urea, dan mineral. Hijauan yang digunakan adalah rumput raja. Pakan diberikan dua kali sehari pada pukul 08.00 WIB dan 15.00 WIB, sedangkan air minum untuk ternak diberikan secara $a d$ libitum.

Sampel yang digunakan adalah pakan suplemen sabun kalsium, bungkil kedelai tanpa proteksi, dan rumput pangola. Kemudian sampel tersebut digiling menggunakan wiley mill dengan diameter lubang saringan ukuran $1 \mathrm{~mm}$.

Pengukuran kecernaan in vitro yang dilakukan mengacu pada prosedur Tilley dan Terry (1963) yang telah dimodifikasi oleh Utomo (2010), dimana terdapat perbedaan yakni pada prosedur tahap I ke tahap II tanpa adanya proses pencucian residu, sehingga langsung dilakukan penambahan $\mathrm{HCl}$ dan pepsin. Selain itu, pada prosedur Utomo (2010) materi, sampel, reagen dan volume tabung reaksi yang digunakan adalah setengah dari prosedur Tilley dan Terry (1963).

Preparasi sampel yang digunakan ditimbang sebanyak $0,25 \mathrm{~g}$ menggunakan timbangan analitik, lalu dimasukkan ke dalam tabung reaksi $50 \mathrm{ml}$ dan diinkubasikan pada suhu $39^{\circ} \mathrm{C}$ selama semalam agar kondisinya sama seperti di dalam rumen. Pengambilan cairan rumen. Pengambilan dilakukan pada pagi hari sebelum ternak diberi pakan. Cairan rumen diambil dari sapi PO betina menggunakan aspirator, spite, dan thermos. Thermos sebelumnya diisi dengan air hangat (suhu $39^{\circ} \mathrm{C}$ ) sampai penuh, kemudian dibuang sebelum diisi dengan cairan rumen.Cairan rumen diambil dengan menggunakan aspirator, lalu dimasukkan ke dalam thermos sampai penuh untuk mencegah adanya oksigen. Kemudian cairan rumen dari thermos disaring dengan menggunakan kain kasa dan dimasukkan ke dalam erlenmeyer sambil dialiri gas $\mathrm{CO}_{2}$ dan diinkubasikan pada suhu $39^{\circ} \mathrm{C}$. Kemudian ditambahkan 
larutan McDougall (saliva buatan).

Sampel yang akan diuji dan telah digiling halus $1 \mathrm{~mm}$ kemudian ditimbang sebanyak 0,25g.Setelah itu dimasukkan ke dalam tabung reaksi volume $50 \mathrm{ml}$ dan selanjutnya diinkubasikan ke dalam waterbath dengan suhu $39^{\circ} \mathrm{C}$ selama 12 jam. Pada tahap satu, setelah 12 jam, tabung yang sudah berisi sampel tadi kemudian diisikan dengan campuran antara cairan rumen dengan larutan McDougall dengan perbandingan 1 cairan rumen : 4 larutan McDougall dan selanjutnya diinkubasikan lagi ke dalam waterbath. Tahap kedua untuk mengetahui kecernaan pasca rumen ialah dengan pemberian $\mathrm{HCl} 20 \%$ ke dalam tiaptiap tabung reaksi sebanyak $3 \mathrm{ml}$ (dengan cara pemberian: 0,$5 ; 0,5 ; 1 ; 1 \mathrm{ml})$ dan setelah itu ditambahkan pepsin 5\% sebanyak 1 ml. Pada tahap kedua dilakukan pengamatan pada 48 jam kedua. Untuk setiap satu titik inkubasi dari perlakuan, blanko dan standar yang diinkubasikan dilakukan replikasi sebanyak 5 kali. Blanko adalah tabung yang diisi tanpa sampel perlakuan, fungsinya sebagai faktor koreksi.Standar adalah tabung yang diisi dengan rumput pangola. Penggojogan dilakukan secara manual setiap 8 jam sekali. Selanjutnya residu yang tersisa dalam tabung disaring dengan crucible yang telah diisi dengan glass wool yang sudah diketahui berat konstannya. Kemudian residu bersama glass wool dipanaskan dalam oven suhu $105^{\circ} \mathrm{C}$ selama 24 jam dan ditimbang, kemudian dilanjutkan kembali dengan proses pengabuan.

\section{Analisis data}

Data yang diperoleh dianalisis variansi menggunakan rancangan acak lengkap pola searah. Hasil pengamatan diuji menggunakan analisis varian. Perbedaan pengaruh perlakuan diuji menggunakan uji Duncan Multiple Range Test (DMRT).

\section{HASIL DAN PEMBAHASAN}

Kecernaan in vitro merupakan salah satu metode untuk mengetahui persentase hilangnya kandungan nutrien bahan pakan selama proses fermentasi oleh mikrobia rumen yang disimulasikan di dalam rumen. Dengan diketahuinya kecernaan suatu bahan pakan, khususnya pada penelitian yang bertujuan untuk memproteksi asam lemak maupun protein pakan, maka nlai kecernaan ini menjadi penting untuk dapat digunakan sebagai parameter atau untuk mengetahui kestabilan produk bahan pakan tersebut di dalam rumen.

Hasil evaluasi kecernaan invitro tahap 1 dan tahap 2 disajikan pada Tabel 1.dan Tabel 2.

Kecernaan ransum mencerminkan kualitas ransum yang diberikan pada ternak, kecernaan bahan kering (KcBK) mencerminkan sejumlah ransum yang secara umum dapat tertahan di dalam tubuh ternak dan tidak dikeluarkan melalui feses, sedangkan kecernaan bahan organik (KcBO) secara khusus memperlihatkan bahan organik ransum yang tertinggal di dalam tubuh ternak. Pada sistem pencernaan rumen (tahap 1 in vitro) dalam penelitian ini P1 berpengaruh sangat nyata terhadap kecernaan bahan kering $(\mathrm{KcBK})$ dan kecernaan bahan organik $(\mathrm{KcBO})$. Nilai kecernaan bahan kering P1 sebesar 24,46\%. Nilai ini lebih rendah bila dibandingkan

Tabel 1. Kecernaan bahan kering (KcBK) in vitro (\% BK)

\begin{tabular}{llcc}
\hline \multirow{2}{*}{ Perlakuan } & \multicolumn{2}{c}{ KcBK } \\
\cline { 3 - 4 } & & Rumen & Pasca rumen \\
\hline P1 & Hidrolisat darah dan minyak ikan lemuru & $24,46^{\mathrm{a}}$ & $69,04^{\mathrm{a}}$ \\
P2 & Bungkil kedelai & $75,20^{\mathrm{c}}$ & $90,38^{\mathrm{b}}$ \\
P3 & Rumput pangola & $50,81^{\mathrm{b}}$ & $63,24^{\mathrm{a}}$ \\
\hline
\end{tabular}

$\mathrm{a}, \mathrm{b}, \mathrm{c}$ superskrip yang berbeda pada satu kolom menunjukkan kecernaan yang berbeda $(\mathrm{P}<0,01)$ 
Tabel 2. Kecernaan bahan organik (KcBO) in vitro (\% BK)

\begin{tabular}{llcc}
\hline \multicolumn{2}{c}{ Perlakuan } & \multicolumn{2}{c}{ KcBO } \\
\cline { 3 - 4 } & & Rumen & Pasca rumen \\
\hline P1 & Hidrolisat darah dan minyak ikan lemuru & $27,85^{\mathrm{a}}$ & $66,71^{\mathrm{b}}$ \\
P2 & Bungkil kedelai & $75,66^{\mathrm{c}}$ & $88,23^{\mathrm{c}}$ \\
P3 & Rumput pangola & $58,68^{\mathrm{b}}$ & $59,21^{\mathrm{a}}$ \\
\hline a, b, c & superskrip yang berbeda pada satu kolom menunjukkan kecernaan yang berbeda \\
$(\mathrm{P}<0,01)$ &
\end{tabular}

dengan P2 yakni sebesar $75,20 \%$, dan P3 sebesar 50,81\%. Sedangkan untuk KcBO nilai terendah adalah $\mathrm{P} 1$ sebesar 27,85\%, kemudian P3 sebesar 58,68\% dan tertinggi P2sebesar75,66\%. Kecernaan bahan kering dan bahan organik P1 lebih rendah bila dibandingkan dengan P2 dan P3.Hal ini menunjukkan bahwa terdapat kemampuan perlindungan bahan pakan pada P1 (pakan suplemen terproteksi) terhadap kecernaan mikrobia di dalam rumen.

Hasil KcBO P1 di dalam pencernaan rumen pada penelitian ini lebih rendah bila dibandingkan dengan penelitian Ueda et al., (2003) yakni lemak terproteksi berbahan linseed oil dengan $\mathrm{KcBO}$ sebesar 43,4\% dan juga lebih rendah bila dibandingkan dengan penelitian Kowalski (1997), KcBK lemak terproteksi berbahan baku minyak kanola $62,6 \%$ dan $\mathrm{KcBO}$ kombinasi minyak kanola dengan bungkil kedelai sebesar $63,7 \%$.

Hal ini disebabkan pakan suplemen terproteksi yang dihasilkan dari proses penyabunan pada campuran minyak ikan lemuru dengan hidrolisat darah dapat menjadi agen proteksi sehingga berdampak pada menurunnya nilai kecernaan bahan kering dan bahan organik pada pencernaan rumen. Pembuatan lemak terproteksi $(\mathrm{Ca}-$ Soap) ini dilakukan melalui proses kimiawi yaitu dengan mereaksikan bahan lemak dengan larutan $\mathrm{NaOH}$ yang dikenal dengan proses saponifikasi (penyabunan), setelah itu direaksikan lagi dengan larutan $\mathrm{CaCl}$ supaya diperoleh lemak terproteksi yang bersifat tidak larut dalam air.

Lemak terproteksi merupakan bentuk lemak terlindung dan merupakan sumber lemak yang efektif dalam bahan pakan ternak ruminansia, karena sistem fermentasi rumen tetap normal, kecernaan asam lemaknya tinggi, dan sabun ini dapat dengan mudah dicampur pada beberapa jenis bahan pakan (Jenkins dan Palmquist 1984). Lebih lanjut Jenkins and Lundy (2002), mengatakan bahwa ikatan yang terbentuk antara asam lemak dan garam kalsium pada lemak terproteksi memiliki sifat yang stabil pada $\mathrm{pH}$ netral sehingga tidak mudah mengalami hidrogenasi oleh mikrobia rumen. Akibatnya akan menurunkan nilai kecernaaan bahan kering dan bahan organik pada rumen

Proses penyabunan mengakibatkan asam lemak bergabung dengan garam alkali membentuk sabun.Sabun yang terbentuk ini memiliki ekor hydrophobic dan hydrophilic. Ekor hydrophobic yang menyebabkan molekul sabun terlindung dari air (Fessenden dan Fessenden, 1986). Hal ini menyebabkan enzim mikroorganisme rumen tidak bisa mencerna bahan pakan yang diproteksi karena media reaksinya berupa air, sehingga mengakibatkan penurunan nilai kecernaan bahan kering dan bahan organik di dalam rumen.

Proses penyabunan mengakibatkan asam lemak bergabung dengan garam alkali membentuk sabun.Sabun yang terbentuk ini memiliki ekor hydrophobic dan hydrophilic. Ekor hydrophobic yang menyebabkan molekul sabun terlindung dari air (Fessenden dan Fessenden, 1986). Hal ini menyebabkan enzim mikroorganisme rumen tidak bisa mencerna bahan pakan yang diproteksi karena media reaksinya berupa air, sehingga mengakibatkan penurunan nilai kecernaan bahan kering dan bahan organik di dalam rumen.

Kecernaan bahan kering ( $\mathrm{KcBK})$ dan kecernaan bahan organik (KcBO) tahap dua (pasca rumen) pakan suplemen terproteksi 
(P1) berpengaruh sangat nyata terhadap $\mathrm{KcBK}$ dan KcBO P2 dan P3. Nilai KcBK terendah pada pencernaan pasca rumen adalah P3 (63,24\%), kemudian P1 $(69,04 \%)$ dan nilai kecernaan $\mathrm{KcBK}$ tertinggi adalah P2 (90,38\%). Sedangkan untuk KcBO, nilai terendah adalah P3 (59,21\%), kemudian P1 $(66,71 \%)$ dan KCBO tertinggi $\mathrm{P} 2(88,23 \%)$.

Dilihat dari nilai kecernaan in vitro bahan kering dan bahan organik tahap II terdapat perbedaan yang sangat nyata antar perlakuan. Nilai KcBO P1 pada penelitian ini lebih tinggi bila dibandingkan dengan penelitian Kowalski (1997), yakni KcBO pasca rumen lemak terproteksi berbahan baku minyak kanola 40,8\% dan kombinasi minyak kanola dengan bungkil kedelai sebesar 40,4\%. Hal ini menunjukkan tingkat kecernaan dan penyerapan $\mathrm{P} 1$, lebih baik walaupun tingkat kecernaannya masih dibawah bungkil kedelai tanpa proteksi sebesar $88,23 \%$.

Schaefer (2000), mengatakan bahwa ikatan pada lemak terproteksi bersifat riversibel (dapat lepas kembali) pada kondisi asam. Sabun yang dihasilkan bersifat stabil (tidak mudah mencair atau terurai) dalam cairan rumen yang mempunyai $\mathrm{pH}$ netral, namun ikatan $\mathrm{Ca}$ dan asam lemak pada saat melewati abomasum yang mempunyai $\mathrm{pH}$ sangat asam akan lepas menghasilkan ion Ca dan asam lemak bebas dan selanjutnya masuk usus halus dan diserap pada usus halus. Pada saat masuk usus besar yang mempunyai $\mathrm{pH}$ netral sisa ion $\mathrm{Ca}$ dan asam lemak tidak membentuk sabun kembali.

Fernandez (1999), mengatakan bahwa mekanisme proteksi rumen terhadap lemak terproteksi tidak didasarkan pada titik cair asam lemak akan tetapi berdasarkan pada level keasaman atau $\mathrm{pH}$ rumen dan usus halus. Lemak terproteksi akan tetap utuh pada lingkungan netral, $\mathrm{pH} 7$ misalnya, tapi akan terurai dalam lingkungan asam, $\mathrm{pH}$ 3 misalnya. Normalnya $\mathrm{pH}$ rumen $6,5-6,8$ dimana keutuhan akan lemak terproteksi ini tetap terjaga. Lemak terproteksi ini akan lolos dari proses biohidrogenasi oleh mikroorganisme rumen, tidak mengganggu aktivitas rumen yang normal dan langsung melewati rumen. Sedangkan di daerah abomasum, lemak terproteksi berada pada suatu lingkungan asam, $\mathrm{pH} 2-3$, sehingga secara langsung lemak terproteksi akan terurai dalam bentuk kalsium dan asam lemak. Pada saat ini asam lemak akan terbebas, mudah dipecah dan diserap oleh tubuh.

\section{KESIMPULAN}

Pakan suplementerproteksi cukup efektif/lebih tahan dari degradasi mikrobia di dalam rumen dari pada pakan tanpa perlakuan proteksi, sertadapat terdegradasi dan tercerna di dalam abomasum sampai dengan usus halus.

\section{UCAPAN TERIMAKASIH}

Penulis mengucapkan terimakasih kepada Direktorat Jenderal Pendidikan Tinggi, Kementrian Riset, Teknologi dan Pendidikan Tinggi Republik Indonesia yang telah memberikan dana penelitian Hibah Doktor, sehingga penelitian ini dapat terlaksana dengan baik.

\section{DAFTAR PUSTAKA}

Agus, A. 2012. Bahan Pakan Konsentrat Untuk Sapi. Citra Aji Parama, Yogyakarta.

Aharoni, Y., A.Orlovand A. Brosh. 2004.Effect of high-forage content and olseed supplementation of fattening diets on conjugated linoleic acid (CLA) and trans fatty acids profiles of beef lipid fractions. J. Anim.Sci. and Techno. 117: 43-60.

Ashes, J.R., E. Fleckand T. W. Scott. 1995. Dietary manipulation of membrane lipids and its implications for their role in the production of second messenger. In: W.V. Engerhardt, S.L. Marek, G. Breves and D. Giesecke. (eds): Ruminant Physiology: Digestion, Metabolism, 
Growth and Reproduction. Ferdinand Enke Verlag. Stuttgart. pp : 373-385.

Fernandez, J.L. 1999. Rumen by-pass fat for dairy diets: when to use which type. Feed International. Agust. P: 18-21.

Fessenden, R. J. and J. S. Fessenden. 1986. Kimia organik. Erlangga, Jakarta.

Jenkins, T.C., and F. Lundy. 2002. Feeding various fat sources to lactating dairy cows and their effect on milk quality. http://www.das.psu.edu/researchextension/dairy/nutrition/pdf/jenkinsfat-sources-and-effects-on-milkquality-2001.pdf.

Jenkins, T.C. dan D.L. Palmquist. 1984. Effect of Fatty Acid or Calcium Soaps on Rumen and Total Nutrient Digestibility of Dairy Rations. J. Dairy Sci. 67 : 978 - 986.

Johnson, K.A., R.L. Kincald, H.H.

Westberg, C.T. Gaskins, B.K. Lamb, and J.D. Conrath. 2002. The effect of oilseed in diets of lactating cows on milk production and methane emissions. J. Dairy Sci. 85: 15091515.

Kamal, M. 1998. Bahan Pakan Dan Ransum Ternak. Laboratorium Makanan Ternak Jurusan Nutrisi dan Makanan ternak. Fakultas Peternakan. UGM. Yogyakarta.

Kowalski, Z. M. 1997. Rumen fermentation, nutrient flow to the duodenum, and digestibility in bulls fed calcium soaps of rapeseed fatty acids and soya bean meal coated with calcium soaps. Anim. Feed sci. Technol. 69: $298-303$.
Pramono. A, Kustono, D. T. Widayati, P. P. Putro,E.Handayanta dan H.Hartadi. 2013.Evaluasi Proteksi Sabun Kalsium Sebagai Pakan Suplemen BerdasarkanKecernaan Bahan Kering, Bahan Organik dan pH In Vitro di dalam Rumen DanPasca Rumen. J. Sains Peternakan. Vol 11 No 2.

Pramono, A., Kustono., P. P. Putro., D.T.Widayati., dan H.Hartadi. 2014. Dietary Supplementation of Protected Sardine Fish Oil on Milk Production and Quality of Dairy Cows. Proceeding The $16^{\text {th }}$ AsianAustralasian Association of Animal Production Congress. Yogyakarta . November 10-14. Indonesia.

Schaefer, D.M. 2000. Potential for Altering Quality of Muscle and Milk from Ruminants: Antioxidants In Muscle. Wiley Interscience, New York.

Tilley, J. M. A. and R. A. Terry. 1963. A two stage technique for in vitro digestion of forage crops. J. British Grassland Society. 18: 104 - 111.

Ueda. K, A. Ferlay, J. Chabrot, J. J. Loor, Y. Chilliard, and M. Doreau. 2003. Effect of linseed oil supplementation on ruminal digestion in dairy cows fed diets with different forage:concentrate ratios. J. Dairy Sci. 86:3999-4007

Utomo, R. 2010. Modifikasi metode penetapan kecernaan in vitro bahankering atau bahan organik. Sintesis. 5: 1 - 11. 